\title{
Evaluation of Low or High Permeability of Fractured Rock using Well Head Losses from Step-Drawdown Tests
}

\section{단계양수시험으로부터 우물수두손실 항을 이용한 단열의 고·저 투수성 평가}

\author{
Byung-Woo Kim1), Hyoung-Soo Kim*, Geon-Young Kim and Yong-Kwon Koh \\ Korea Atomic Energy Research Institute, 989-111 Daedeok-Daero, Yuseong-Gu, Daejeon \\ *Jungwon University, 85 Munmu-ro, Geosan-gun, Chungbuk \\ 김병우1), 김형수*, 김건영, 고용권 \\ 한국원자력연구원, 대전시 유성구 대덕대로 989번길 111 \\ *중원대학교, 충청북도 괴산군 문무로 85
}

(Received october 10, 2011 / Received January 30, 2012 / Approved February 08, 2012)

\begin{abstract}
The equation of the step-drawdown test " $s_{w}=B Q+C Q^{p}$ " written by Rorabaugh (1953) is suitable for drawdown increased non-linearly in the fractured rocks. It was found that value of root mean square error (RMSE) between observed and calculated drawdowns was very low. The calculated $C$ (well head loss coefficient) and $P$ (well head loss exponent) value of well head losses $\left(C Q^{p}\right)$ ranged $3.689 \times 10^{-19} \sim 5.825 \times 10^{-7}$ and $3.459 \sim 8.290$, respectively. It appeared that the deeper depth in pumping well the larger drawdowns due to pumping rate increase. The well head loss in the fractured rocks, unlike that in porous media, is affected by properties of fractures (fractures of aperture, spacing, and connection) around pumping well. The $C$ and $P$ value in the well head loss is very important to interpret turbulence interval and properties of high or low permeability of fractured rock. As a result, regression analysis of $C$ and $P$ value in the well head losses identified the relationship of turbulence interval and hydraulic properties. The relationship between $C$ and $P$ value turned out very useful to interpret hydraulic properties of the fractured rocks.
\end{abstract}

Key words : step-drawdown test, fractured rocks, least squares method, well head loss, high or low permeability

\section{요 약}

Rorabaugh(1953)에 의해 재정리된 단계양수시험 해석해 $s_{w}=B Q+C Q^{p}$ 는 단열암반대수층에서 비선형 으로 증가하는 수위강하에 매우 적합하며, 현장에서 관측된 수위강하 값과 추정된 수위강하 사이의 제곱 근 평균제곱오차(RMSE) 값이 매우 낮음을 보여주었다. 우물수두손실 $\left(C Q^{p}\right)$ 의 $C$ 값은 $3.689 \times 10^{-19} \sim 5.825$ $\times 10^{-7}, P$ 값은 3.459 8.290의 범위로 산정되었으며, 지표로부터 하부심도로 내려 갈수록 양수율 증가에

1) Corresponding Author. E-mail : bwkim@kaeri.re.kr 
따른 수위강하는 매우 크게 나타났다. 단열암반대수층에서의 우물수두손실은 다공질매질에서와 달리 단 열특성(단열의 틈, 간격, 상호 연결성)에 의한 영향으로 나타나므로, 우물수두손실의 C 와 $P$ 값은 단열암 반대수층의 난류구간과 고·저 투수성 단열암반의 특성을 해석하는데 매우 중요하다. 그 결과, 우물수두 손실 항의 $C$ 와 $P$ 값에 대한 회귀분석 결과로부터 암반대수층의 난류구간과 수리특성의 관계가 파악되었 으며, $C$ 와 $P$ 값의 관계가 단열암반대수층의 수리특성 해석에 있어 매우 유용함을 확인할 수 있었다.

중심단어 : 단계양수시험, 단열 암반, 최소제곱법, 우물수두손실, 고 · 저 투수성

\section{I. 서 론}

우리나라 대수층은 대부분 파쇄된 암반대수층의 특성을 가 지고 있으며, 다공질매질에 비하여 단열암반대수층에 대한 연구가 미비한 실정이다. 그러므로 우리나라 대수층 개발에 맞는 여러 가지 양수시험에 관련된 연구는 매우 중요하며, 여 러 시험 중에 단열암반대수층(fractured aqufier)으로부터 단 계양수시험(step-drawdown test)을 이용한 수리특성 분석은 시간과 비용측면에서 매우 효과적일 것이다.

일반적인 단계양수시험은 Jacob(1947)에 의해 처음으로 소 개되었으며[1], Rorabaugh(1953)는 Jacob의 그래픽 방법을 이용하여 $s_{w}=B Q+C Q^{p}$ 으로 표현하였다[2]. Jacob 이후에도 시험해석에 대한 그래픽, 산술연산, 수치 및 최적화 방법 그 리고 반복법들이 개선되거나 개발되어왔다. 그러나 단열암반 대수층에서 단계양수시험을 이용한 투수성 단열에 대한 연구 는 매우 미미한 실정이다.

국외의 경우 Jacob, Rorabough, Lennox, Sheanhan, Birsoy and Summers 그리고 Kruseman and de Ridder는 그 래픽 방법을 이용하였으며[1 6], Bierschenk와 Kasenow는 산술연산 방법[7][8], Labadie and Helweg, Sheahan, Gupta, Singh 및 Shekhar는 수치 및 최적화 방법을 제시하였다[9 13]. Miller and Weber는 반복법을 이용하여 최적의 수리상수 $B, C$ 및 $P$ 값을 산정하는 방법을 제시하였다[14]. 그리고 Tonder et al.는 단계양수시험 및 다중 양수율 시험(multi-rate test)으로부터 두 개의 비선형 모델해석을 이용한 대수층의 변 형(deformation), 유동차원, 분리단열(discrete fracture)에서 의 배수(dewatering) 등에 관한 여러가지 요인들을 단열암반 대수층을 통하여 설명하였다[15].

국내에서는 단계양수시험 해석 시 각 단계별 시간선택이 대수층 우물상수(well parameter) 등에 상당한 오차 발생과 취수량의 적정채수량 산정의 문제점에 관한 연구결과를 제시 하였다[16][17]. 그리고 단계양수시험 해석 시 단열암반대수층 내의 단열특성이 유체의 속도를 지배하므로 우물수두손실 항
$\left(C Q^{p}\right)$ 으로부터 정확한 $P$ 값의 산정은 단열암반대수층을 이 해하는 중요한 요인으로 설명하였다[18]. 그 뿐만 아니라, $\mathrm{Jacob}$ 이 제시한 $P=2.0$ 로 산정할 경우 우물상수가 우물효율에 미치는 영향과 단열암반대수층에 적용시 우물효율 평가에 대 한 부적절성이 제시되었으며, 그 반면에 다공질매질과 단열 암반대수층으로부터 비선형모델의 적합성을 제시하였다[19].

단열암반대수층에서 지하수유동은 전체단열들을 통한다는 것이 아니라 일부 투수성 단열에 의해 지하수유동이 지배받는 다는 채널(channel) 개념을 가정하여 수리단열(hydraulic fracture)에서의 지하수유동을 해석한 것이다[20][21]. 이와 같이 단열암반대수층에서 양수시험시 시간에 따른 급격한 수위강하 는 비선형 형태를 보이기 때문에 선형 모델을 적용할 경우 상당 한 오차가 발생하게 되며, 우물효율 평가 저하의 직접적인 원인 을 규명하는데 불확실성을 보일 수 있다[9]. 그러므로 비선형 모 델로 산정된 결과는 최적의 우물상수 산정뿐만 아니라 단열암 반대수층의 수리단열을 연구하는데 있어서 매우 중요하다.

따라서 본 논문에서는 기존에 수행된 단계양수시험으로부 터 고투수성 단열특성을 가지는 2개의 관정(CR-1, SR-1; [19]) 과 저투수성 단열특성을 가지는 1 개의 관정(CR-2)으로부터 단 열의 고 - 저 투수성 연구를 수행하였다. 먼저 단열암반대수층 에서 단계양수시험 시 양수율에 따른 급격한 수위강하 값에 적합한 모델을 검토하기 위하여 선형 방법(Jacob's graphic method)과 비선형 방법(Labadie and Helweg's least-squares method)을 비교 · 분석하였다. 그리고 단열암반층대수층에 매우 적합한 비선형 모델의 최소제곱법으로 산정된 우물수두 손실 항 $\left(C Q^{p}\right)$ 으로부터 난류흐름 구간과 고 - 저 투수성 단열 들을 분석하는데 목적을 두었다.

\section{II. 지질 및 시험 개요}

본 연구는 충북 청원에 위치하는 CR-1, 2호공과 부산 사직 동 일원에 위치하는 SR-1호공으로부터 단계양수시험을 실시 하였다(Fig. 1). 충북 청원 지역은 운교리층과 쥬라기 대보화 강암류인 화강암류가 분포하고 있다. 그 중에 화강암류는 쥬 라기화강암류로써 청주 화강암, 보은화강암, 흑운모 화강암, 


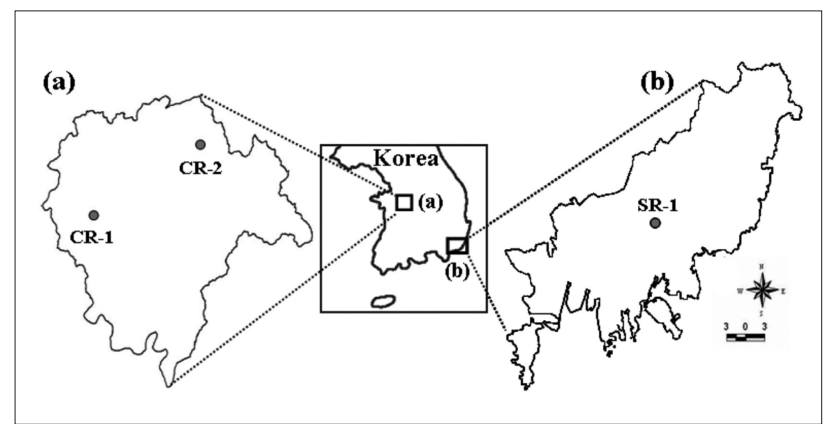

Fig. 1. The well location of the tests site : (a) Cheongwon, Chungbuk province, (b) Sajikdong, and (c) Busan City.

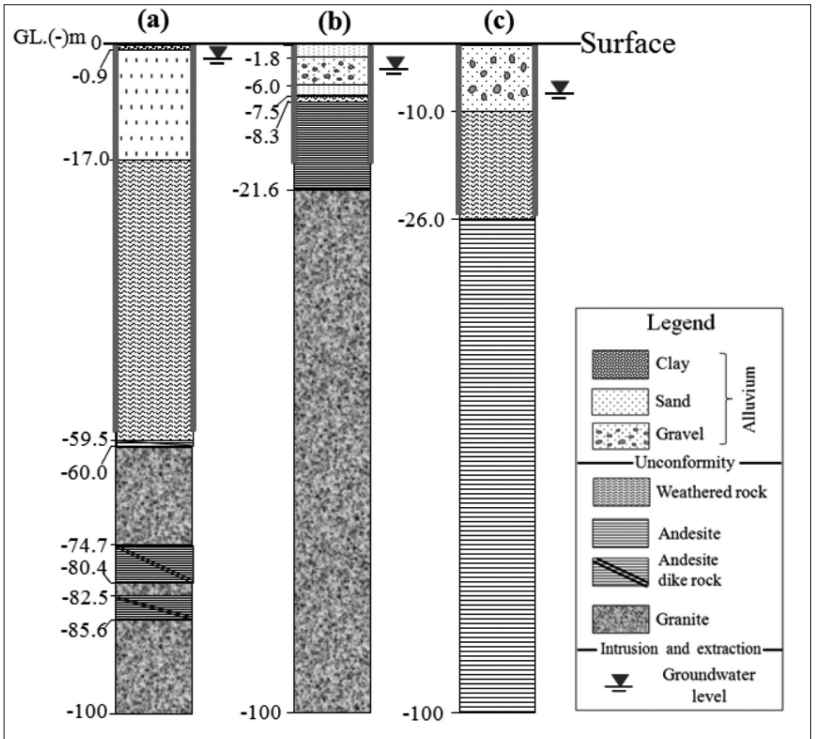

Fig. 2. Geological section of wells in fractured rocks: (a) CR-1 (after [19]), (b) CR-2, and (c) SR-1 (after [19]).

복운모화강암 등이 있으며, Fig. 2(a, b)의 CR-1, 2호공이 위 치한 암상은 청주 화강암이다. 부산 사직동 일원은 백악기 하 양층군에 속하는 퇴적암층인 이천리층, 유천층군의 안산암류 이다. 그리고 이들을 후기에 관입한 화강섬록암으로 구성되 어 있으며, Fig. 2(c)의 SR-1호공이 위치한 암상은 안산암류이 다. 각 양수정이 위치한 지점의 수직적인 지질특성은 상부로 부터 충적층(모래, 자갈, 점토) 및 풍화대 구간이며, 그 하부 에는 단열들이 발달된 암반층이 형성되어 있다.

단열암반층에 굴착된 3개의 양수정에서 단계양수시험이 실 시되었으며[22][23], 각 양수정의 굴착심도, 내경, 케이싱심도 및

Table 1. Test conditions of pumping wells in fractured rocks.

\begin{tabular}{|c|c|c|c|c|}
\hline Well site & Well depth & Well diameter & Casing depth & Submersible pump depth \\
\hline CR-1 & 100 & 0.2 & 54 & 90 \\
\hline CR-2 & 100 & 0.2 & 9 & 90 \\
\hline SR-1 & 100 & 0.2 & 25 & 80 \\
\hline
\end{tabular}

수중펌프 설치심도는 Table 1에 정리하였다. 단계양수시험의 양수량은 V-notch로 측정하였으며, 양수 단계는 각 지점으로 부 터 최소 5단계에서 최대 6단계로 실시하였다. 그 결과는 Fig. 3 에서 보는바와 같이 시간별 수위강하 그래프로 나타내었다.

\section{III. 배경 이론}

\section{가. 우물상수 산정}

단계양수시험은 양수정 및 대수층에 관한 많은 정보(우물
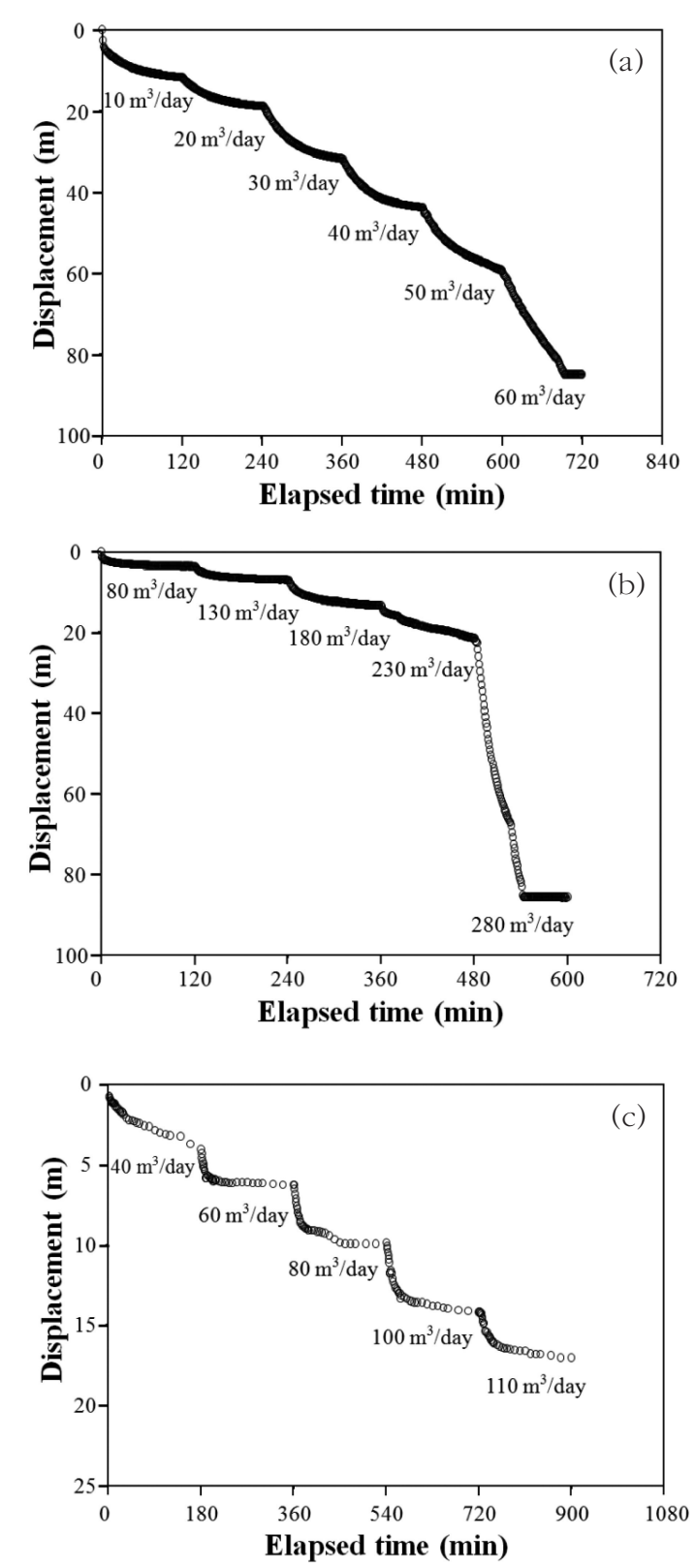

Fig. 3. Plot of step-drawdown test data in fractured rocks: (a) CR-1 (after [19]), (b) CR-2, and (c) SR-1 (after [19]). 
효율, 수량, 개발 가능량, 최대양수량, 적정양수량)를 제공 하는 현장시험 방법으로 Jacob(1947)에 의해 제안되었으며, 양수율에 대한 수위강하의 관계를 해석할 수 있는 방법이 다.

이에 대한 다공질매질과 단열암반대수층에서 단계양수시 험으로부터 최적의 우물상수인 대수층수두손실계수 (aquifer head loss coefficient; $B$ ), 우물수두손실계수 (well head loss coefficient; $C$ ) 그리고 우물수두손실지수 (well head loss exponent; $P$ )를 산정하기 위하여 선형 모델의 그 래픽 방법(Jacob's method)과 비선형 모델의 최소제곱 방 법(Labadie and Helweg's least-squares method)을 이용하 였다(Table 2). Jacob의 그래픽 방법은 단계양수시험 자료 를 분석하기 위한 가장 일반적인 그래픽 기법이다[24][25]. 이러한 그래픽 방법은 우물손질지수 $P$ 가 2 일 때, $s_{w}=$ $B Q+C Q^{p}$ 에서 양변을 $Q$ 로 나누면, $s_{w} / Q$ 가 비수위강하량 이 된다.

비선형 모델은 $s_{w}=B Q+C Q^{p}$ 해에서 $B, C$ 및 $P$ 를 산정하 기 위하여 최소제곱법을 이용한 수치해석 방법[9]으로, 오차 $(E(P))$ 가 최소가 되는 $B, C$ 및 $P$ 값을 산정하게 된다. 식 (1), 식(2), 식(3) 으로부터 $B$ 와 $C$ 에 대한 편미분으로 최소제곱 값을 산정하기 위한 연립방정식이며, $B, C$ 및 $P$ 값들을 산정 하기 위하여 비선형 최소제곱법을 이용하였다[19].

$$
\begin{gathered}
E(P)=\operatorname{Min}_{B, C} \sum_{i=1}^{N}\left[s_{i}-\left(B Q_{i}+C Q_{i}^{P}\right)\right]^{2}=0 \ldots . . . \\
\frac{\partial E(P)}{\partial B}=\sum_{i=1}^{N}\left[s_{i}-\left(B Q_{i}+C Q_{i}^{P}\right)\right] Q_{i}=0 \\
\frac{\partial E(P)}{\partial C}=\sum_{i=1}^{N}\left[s_{i}-\left(B Q_{i}+C Q_{i}^{P}\right)\right] P C Q_{i}^{P-1}=0
\end{gathered}
$$

여기서 $B$ 는 대수층수두손실계수, $C$ 는 우물수두손실계 수, $B Q$ 는 층류에 의한 대수층수두손실, $C Q^{2}$ 는 난류에 의한 우물수두손실, $P$ 는 우물수두손실지수, $Q$ 는 양수율 $\left[L^{3} /\right.$ $T], s_{w}$ 는 양수정에서의 수위강하이다.

\section{나. 난류에 의한 우물수두손실}

양수정에서 양수 시 다공질매질에서는 케이싱(casing) 및 스크린(screen), 시추 시 공벽 변형 등의 복합적인 원인에 의 해서 우물수두손실이 발생하게 된다[1]. 그러나 다공질매질과 달리 단열암반대수층에 시추된 양수정의 케이싱은 Fig. 4(a) 에서 보는 바와 같이 지표로부터 풍화대까지 설치하며, 그 이 후 구간은 나공(open hole) 상태의 관정이 많다. 시추 시 충 격으로 인한 양수정 공내 공벽에서 단열이 손상되거나 확장 되는 경향이 있으나, 물리검층 결과에서는 공벽의 단열 손상
에 의한 영향은 크지 않는 것으로 나타났다. 따라서 단열암반 대수층에서의 우물수두손실은 다공질매질에 설치된 스크린 에 의한 우물수두손실과 같은 유사한 요인들을 가지게 된다. 그리고 양수정을 관통하는 단열들은 마치 스크린과 같은 역 할을 하게 되며, 이때 관통된 단열특성에 따라 지하수 유속은 변하게 된다. 즉 지하수 유속의 변화에 따라 층류 및 난류가 발생하게 되는데, 이러한 기하학적인 두 흐름은 레이놀즈 수 (reynolds number, $\mathrm{Re}$ ) $R e=v d / v$ 에 의하여 판별되기도 한다. 여기서 $v$ 는 다르시안의 단위 속도, $d$ 는 다공성기질의 거리 (some length dimension of the porous matrix), $v$ 는 동역학 적 점성계수이다. 층류에 의한 흐름은 점성력이 지배적인 유 동으로서 평탄하면서 일정한 유동의 특징이 나타나며, 이때 레이놀즈 수는 낮게 나타난다. 반면에 난류는 관성력이 지배 적인 유동으로서 불규칙적인 와류(eddy)와 유동변동(flow perturbation) 등의 복잡한 특징으로 레이놀즈 수는 높다[19]. 이때 양수정에서 양수율을 증가할 경우 양수정을 관통하는 단일단열 및 단열 빈도가 낮고 좁은 단열 틈을 따라 흐르는 지하수 속도의 증가와 유입량의 감소로 인하여 양수정 내에 서의 수위강하는 급격히 증가되어 우물수두손실이 크게 발생 하게 된다.

유체의 속도와 관련된 난류는 $C$ 와 $P$ 값의 단열특성과 상관 관계를 가진다고 볼 때, $C$ 와 $P$ 값의 산정은 단열암반대수층 을 해석하는데 매우 유용하다. 이론적으로 양수율과 수위강하 는 Fig. 4(b)와 같이 층류흐름 조건에서 선형으로 비례된다. 그러나 일정한 양수율 이상에서 나타난 난류흐름은 양수율 증 가에 따라 난류흐름 구간이 상대적으로 크게 확장될 경우에 수위강하는 급격히 나타나며, 이때 수위강하는 지수적으로 증 가하게 된다. 즉, 수위강하가 선형적으로 증가하는 층류흐름 구간은 투수성이 높은 구간을 가지게 되고, 수위강하가 지수 적으로 증가하는 난류흐름 구간은 단열을 통한 지하수의 유입 이 급격히 떨어져 투수성이 낮아지게 된다. 따라서 단열암반 대수층으로부터 수위강하가 선형적으로 증가하는 층류흐름은 고투수성 단열구간으로 해석하였으며, 수위강하가 지수적으 로 증가하는 난류흐름은 저투수성 단열구간으로 해석하였다.

\section{IV. 분석결과}

\section{가. 선형과 비선형 모델}

본 연구는 단열암반대수층에서 획득된 단계양수시험 자 료로부터 비선형 모델이 단계양수시험 해석에 매우 적합하 고 효과적임을 제시하기 위하여 선형과 비선형 모델의 우물 상수를 비교 · 분석하였다(Table 2). 그리고 비선형모델[9]로 
Table 2. Value of B, C, RMSE, $\mathrm{P}$, and $R^{2}$

\begin{tabular}{|c|c|c|c|c|c|c|c|c|}
\hline \multicolumn{2}{|c|}{ Well site } & Model & Method & $\begin{array}{c}B \\
\text { (day/m²) }\end{array}$ & $\begin{array}{c}C \\
\left(\text { day }^{\mathrm{P}} / \mathrm{m}^{3 \mathrm{P}-1}\right)\end{array}$ & $P$ & RMSE & $R^{2}$ \\
\hline \multirow{6}{*}{$\begin{array}{c}\text { Fractured } \\
\text { rocks }\end{array}$} & \multirow{2}{*}{ CR-1 } & Linear & Jacob & $9.442 \times 10^{-1}$ & $5.696 \times 10^{-3}$ & 2.000 & 4.1540 & 0.9813 \\
\hline & & Nonlinear & Labadie-Helweg & $1.025 \times 10^{0}$ & $2.185 \times 10^{-9}$ & 5.639 & 1.1808 & 0.9985 \\
\hline & \multirow{2}{*}{ CR-2 } & Linear & Jacob & $-8.819 \times 10^{-2}$ & $1.126 \times 10^{-3}$ & 2.000 & 15.8257 & 0.8369 \\
\hline & & Nonlinear & Labadie-Hely & $4.720 \times 10^{-2}$ & $3.689 \times 10^{-19}$ & 8.290 & 2.7005 & 0.9953 \\
\hline & \multirow{2}{*}{ SR-1 } & Linear & Jacob & $6.379 \times 10^{-2}$ & $7.852 \times 10^{-4}$ & 2.000 & 0.4046 & 0.9957 \\
\hline & & Nonlinear & Labadie-Helweg & $9.369 \times 10^{-2}$ & $5.825 \times 10^{-7}$ & 3.459 & 0.1458 & 0.9994 \\
\hline
\end{tabular}

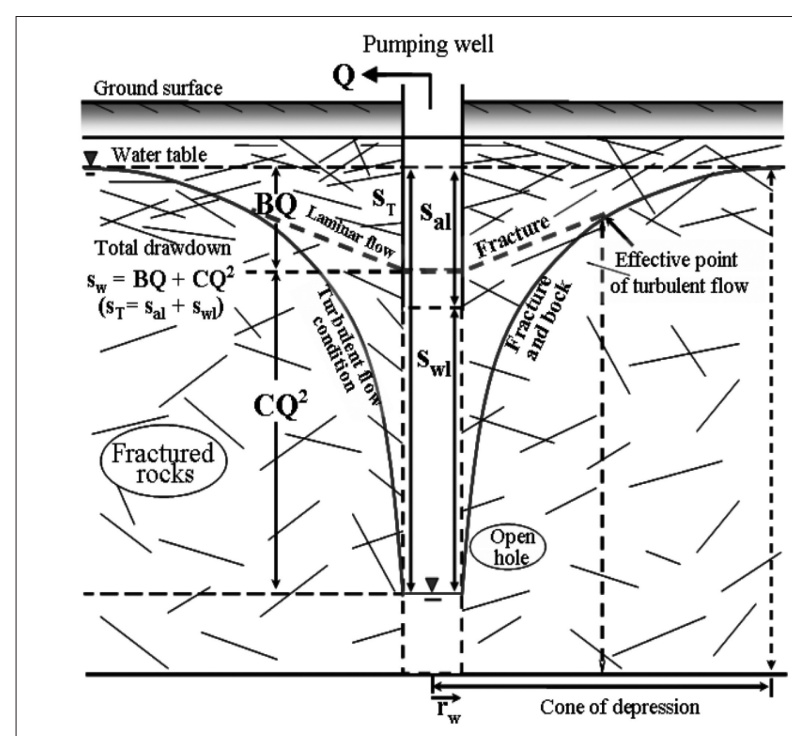

(a)

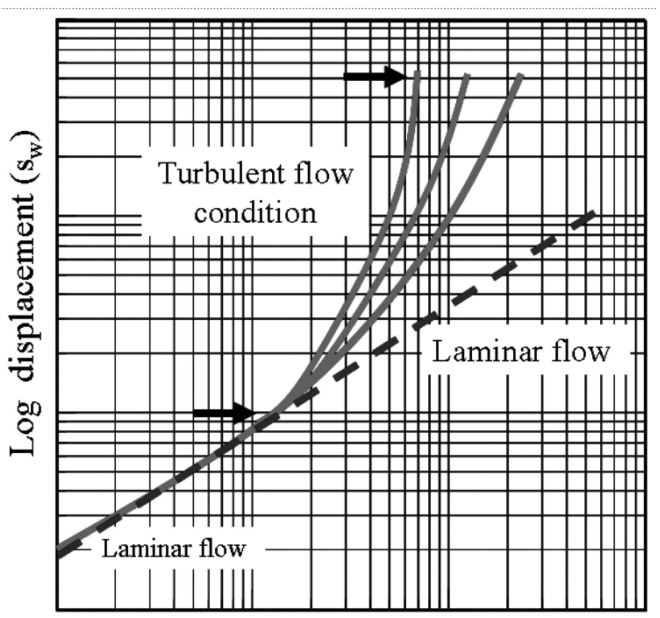

Log pumping rate $(\mathrm{Q})$

(b)

Fig. 4. Components of drawdown in a pumping well : (a) Fractured rocks response to pumping (after [19]), and (b) curve types showing laminar and turbulent flow with an increase in the pumping.

산정된 우물수두손실 항은 단열암반대수층으로부터 고 · 저 투수성 단열특성을 분석하는데 있다.

단열암반대수층으로부터 비선형 모델로 산정된 $B, C$ 및
$P$ 값은 양수율 증가에 따른 수위강하 값과 거의 일치하는 것 으로 나타났다. 이것은 선형 회귀곡선의 경사 및 $\mathrm{y}$-절편의 구조와 관련된 주관적인 오차를 제거하기 때문이다. 그리고 선형 모델로 산정된 CR-1, 2호공은 매우 급격한 수위강하로 인한 우물상수 $(B, C)$ 가 과소평가된다. 이때 CR-1호공에서 의 급격한 수위강하(Step 5 6: $41.09 \mathrm{~m}$ )로 인한 B 와 $C$ 값 은 낮으며, CR-2호공에서는 매우 급격한 수위강하(Step 2 5: $78.91 \mathrm{~m})$ 로 인한 $B$ 의 음(-)의 값과 급한 기울기로 인한 $C$ 값은 조금 큰 값을 보였다. 그리고 SR-1호공의 $B$ 값은 선형 모델 보다 약간 적은 값을 보였으며, $C$ 값은 약간 높게 나타 났다. 이는 선형 방정식이 각 단계 또는 증가된 단계양수의 조합으로 산정된 계수의 평균값으로 결정되기 때문이다. 특 히 수위강하가 매우 급격히 나타나는 CR-1, 2호공에서는 선 형 모델이 적합하지 않음을 보여준다.

단열암반대수층에서 비선형 모델로 적용한 SR-1호공에서 측정된 수위값은 유사한 값을 보였으나, 선형 모델과 비교 할 때 비선형 모델로 산정된 $B$ 값은 조금 낮으며, $C$ 값은 약 간 높게 나타났다. 이는 Jacob 방법의 그래프에서는 직선의 기하학적인 기울기가 나타나기 때문이다. 따라서 CR-1, 2호 공에서의 Jacob 방법을 이용할 경우 지수적으로 매우 급격 히 증가하는 수위강하 그래프에서는 직선의 기하학적인 기 울기가 나타나지 않았다.

상기 결과들을 이용한 단열암반대수층에서의 수위강하는 대수층수두손실과 우물수두손실의 합을 Fig. 5에서 보는 바 와 같이 나타낼 수 있다. 이때 단열암반대수층의 CR-1, 2호 공 및 SR-1호공에서 선형 모델을 이용한 경우 양수율이 크 게 증가 될수록 추정된 수위강하는 과소평가 된다. CR- 1,2 그리고 SR-1호공의 RMSE는 선형 및 비선형 모델을 비교하 였을 때 비선형 모델에서 낮은 값을 보이며, 결정계수 $\left(R^{2}\right)$ 는 선형 보다 비선형 모델에서 높은 값을 보인다. 이때 $P$ 값은 3.459 8.290의 범위로 산정되었으며, 이는 단열암반대수층 에서의 수리특성이 매우 다양하게 나타나는 것을 의미한다.

\section{나. 단열과 우물수두손실과의 관계}

단열암반대수층에서 지하수유동은 단열의 길이(length), 간격(spacing), 틈(aperture), 충전물(infilling materials), 


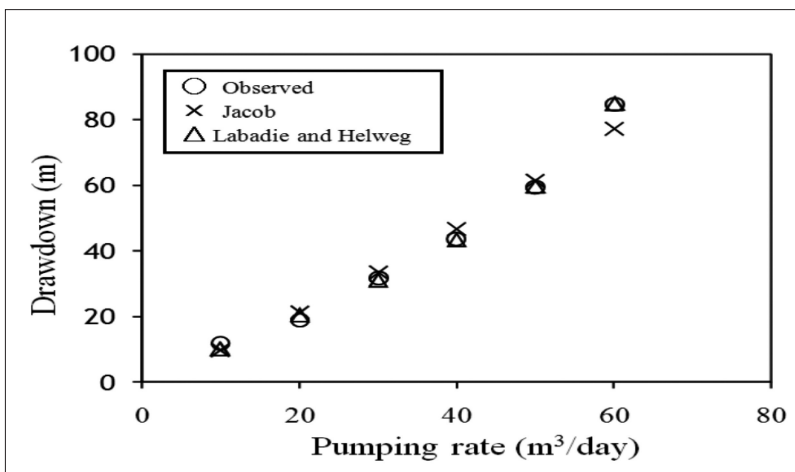

(a)

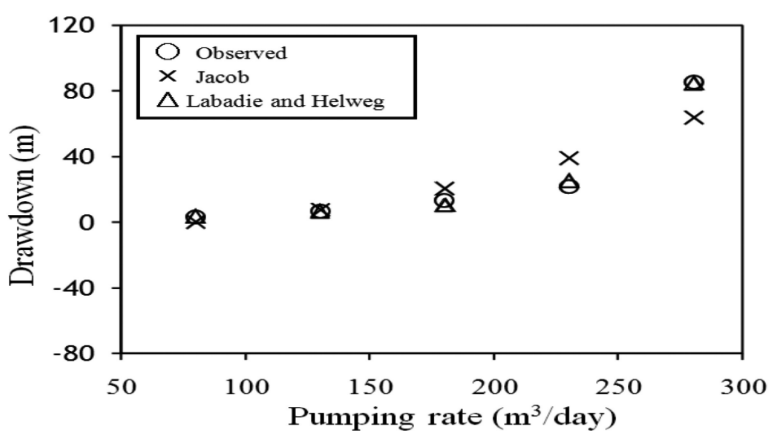

(b)

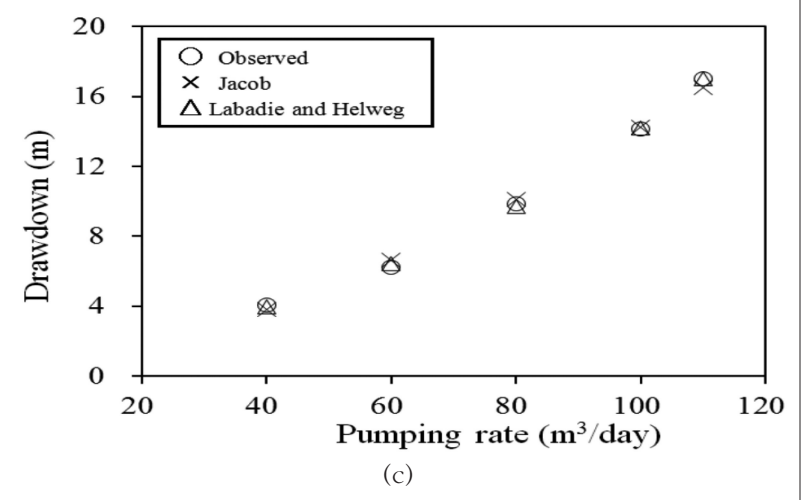

Fig. 5. Comparison between observed and calculated drawdowns ; (a) CR-1 (after [19]), (b) CR-2, and (c) SR-1 (after [19]).

연결성(connectivity), 거칠기(roughness) 등과 같은 단열의 특성에 의해 크게 좌우된다. 특히 지하수유동은 Fig. 6에서 보는바와 같이 단계양수시험 시 수리단열의 상호 연결성에 따라 수위강하가 높거나 낮게 나타난다. Fig. 6(a)에서 CR-1 호공은 상부가 풍화암으로 발달되어 있으며, 하부심도로 내 려 갈수록 단열분포가 매우 적다. Fig. 6(b)에서 CR-2호공은 천부의 단열분포가 높으며, 개구성 단열(open fracture)들 은 지표면하 15 30m 구간에 많이 발달하고 있다. 또한 하 부로 내려 갈수록 단열분포가 적게 나타난다. Fig. 6(c)에서 SR-1호공은 개구성 및 미세 단열(hair fracture)은 전 심도에
걸쳐 고루 발달하고 있다. 일반적으로 단열분포와 지하수 흐름은 상호 상관성을 가지는 것으로 알려져 있으나, CR-2 호공은 CR-1호공 보다 단열분포가 높음에도 불구하고 수위 강하가 매우 급격히 나타난다. 이는 지하수 흐름의 통로가 되는 단열들의 상호 연결성이 약하기 때문인 것으로, 양수 시 양수정으로 향하는 지하수 유속이 증가되어 난류가 발생 하게 된다. 이때 수위강하는 매우 급격히 증가하게 된다.

이와 같이 난류흐름과 관련된 $P$ 값은 우물수두손실에 대 한 지수에 해당하므로 그 값에 따라 우물수두손실이 크게 좌우된다. 그리고 단열암반대수층에서 우물수두손실은 단 열의 특이성에 의해 나타나며, $P$ 값이 크면 양수정에서 난류 구간이 크게 확장되고, $P$ 값이 작으면 난류구간이 작게 확장 된다[2][18], 따라서 단열암반대수층에서 단열분포가 많이 발달되어 있다 하더라도 단열의 상호 연결성이 없으면 Fig 6(b)에서 보는 바와 같이 양수정에서 난류구간이 상대적으 로 확장되어 수위강하는 매우 급격히 증가하게 된다.

단열암반대수층에 설치된 양수정으로부터 각 양수율에 따른 수위강하를 Fig 7과 같이 비선형 모델로 나타내었다. 이 때 $C$ 의 범위는 $3.689 \times 10^{-19} \sim 5.825 \times 10^{-7}, P$ 값은 3.459 8.290의 범위를 보였다. 단열암반대수층에 굴착된 양수정 의 경우 상부의 풍화암과 단열 분포 및 상호연결성이 매우 높은 구간에서는 양수정 내로 2 3차원의 지하수 흐름이 발 생되어 층류흐름이 나타난다. 그리고 양수율 증가시 양수정 에서의 급격한 수위강하는 단열의 상호 연결성과 관련이 있 으며, 양수정으로 유입되는 지하수 흐름은 좁은 단열을 따 라 유입되기 때문에 양수율에 따른 우물수두손실과 난류흐

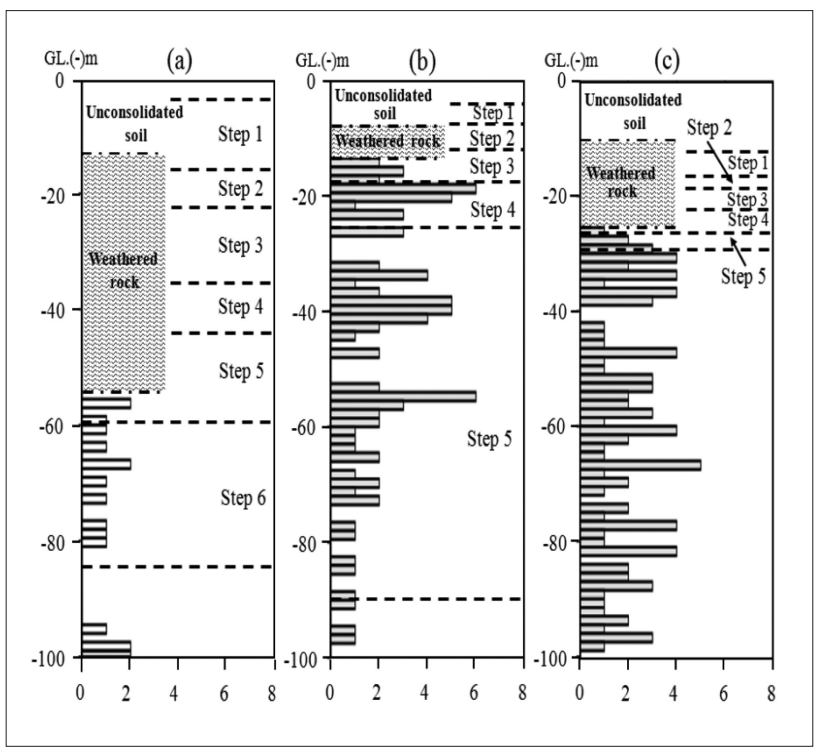

Fig. 6. Comparison of fracture distribution and a particular drawdown during step-drawdown tests; (a) CR-1, (b) CR-2, and (c) SR-1. 


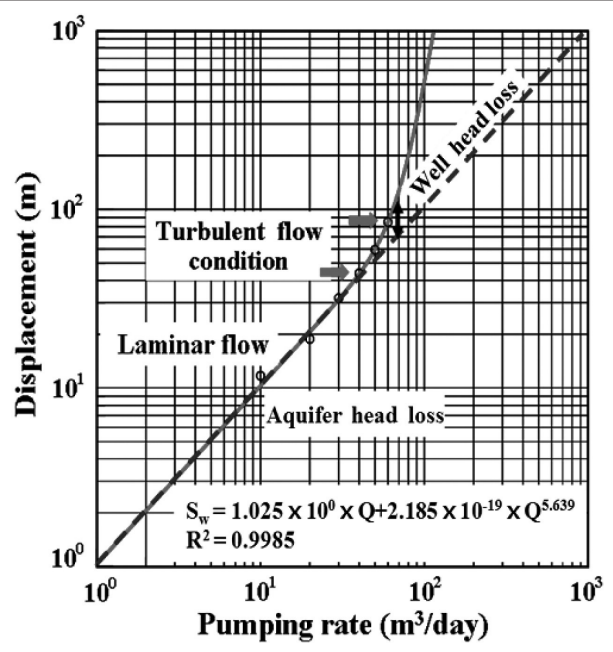

(a)

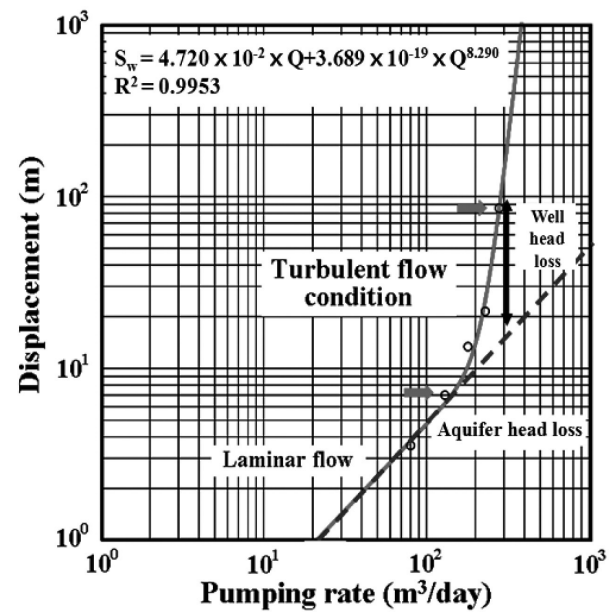

(b)

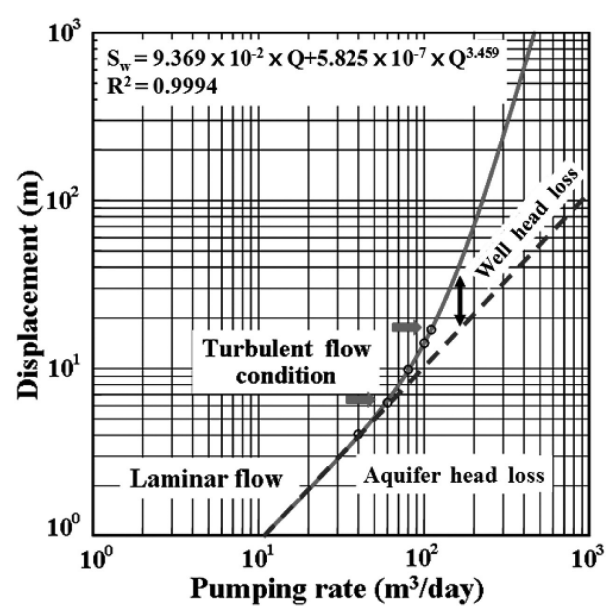

(c)

Fig. 7. Analysis of aquifer head losses and well head losses from step-drawdown tests ; (a) CR-1, (b) CR-2, and (c) SR-1.
름은 관련성이 크게 나타난다. 따라서 양수시험시 양수정 부근으로 유입되는 지하수 흐름은 우물수두손실지수 $P$ 값에 따라 우물수두손실과 난류흐름의 구간이 커지거나 작게 나 타난다. 즉, 양수율 증가에 따라 $P$ 값이 증가하면 우물수두 손실과 난류흐름 구간도 상대적으로 크게 나타나며, 반면에 $P$ 값이 작으면 우물수두손실과 난류구간이 작게 나타난다.

\section{다. 투수성 단열 해석}

양수정에서 양수시 급격한 수위강하는 우물수두손실에 좌 우되며, 이러한 우물수두손실은 단열의 특성에 따라 크게 나 타나거나 작게 나타난다. 이때 우물수두손실 항 $\left(C Q^{p}\right)$ 의 우 물수두손실계수 $(C)$ 와 우물수두손실지수 $(P)$ 값은 단열의 수 보다는 단열의 상호 연결성에 따라 우물수두손실이 좌우되는 주 요인이 된다. 따라서 CR-1, CR-2호공 및 SR-1호공의 C 값 과 $P$ 값에 대한 회귀분석 결과는 Fig. 8 에서 보는바와 같이 반 비례적으로 증가한다. 이에 대한 $C$ 와 $P$ 값의 회귀분석 식은 식 (4)과 같으며, $R^{2}$ 는 0.9245 로 매우 높게 나타났다.

$$
P=1.7940-0.1565 \cdot \ln C
$$

여기서 SR-1호공의 $C$ 가 $1 \times 10^{-7}<C \leq 1 \times 10^{0}$ 일 때 $P$ 는 1.79 $\langle P \leq 4.32$ 의 범위를 가지며, 전체적으로 고투수성 흐름(high permeability)을 보인다. CR-1호공의 $C$ 가 $1 \times 10^{-15}\langle\mathrm{C} \leq 1 \times$ $10^{-07}$ 일 때 $P$ 는 $4.32<P \leq 7.20$ 의 범위를 보였다. 이 때 지표 면하 $3.08 \sim 46.81 \mathrm{~m}$ 의 지하수 흐름은 저투수성 흐름(low permeability)을 보이며, 지표면하 46.81 100m에서는 매 우 낮은 저투수성 흐름(very low permeability)이 나타났다. 그리고 $\mathrm{CR}-2$ 호공의 $C$ 가 $1 \times 10^{-25}\left\langle\mathrm{C} \leq 1 \times 10^{-15}\right.$ 일 때 $P$ 는

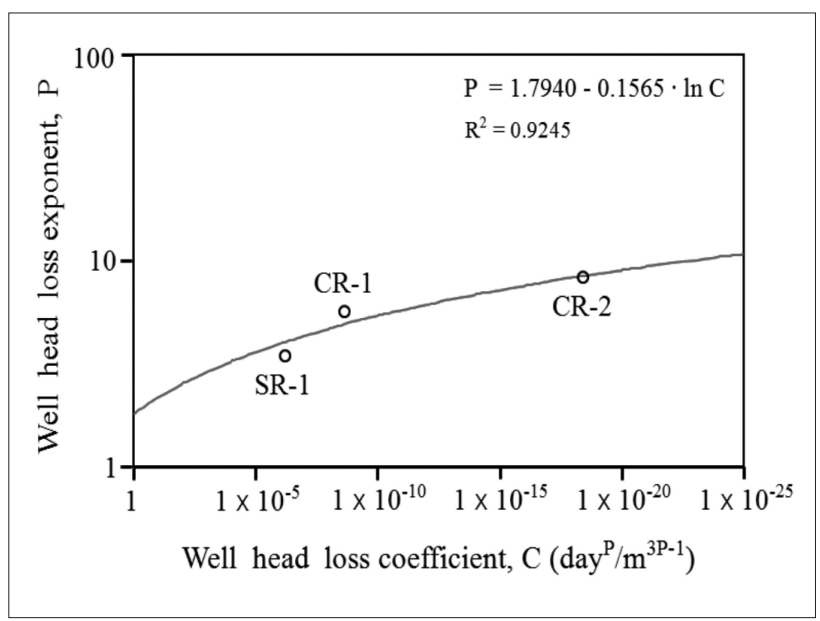

Fig. 8. Regression analysis for value of $C$ (well head loss coefficients) and $P$ (well head loss exponents) in well head losses. 
$7.20<P \leq 10.80$ 의 범위를 가진다. 이때 지표면하 3.80 $10.79 \mathrm{~m}$ 에서는 매우 높은 고투수성 흐름이 나타나며, 지표 면하 10.79 100m에서는 지하수 흐름이 매우 낮은 저투수 성을 보였다. 이와 같이 $C$ 와 $P$ 값이 작게 되면 난류의 영향 이 작기 때문에 층류흐름이 발달되며, $C$ 와 $P$ 값이 크게 되면 대수층의 투수투성은 낮기 때문에 난류흐름의 영향이 크게 나타난다. 그리고 $C$ 값은 매우 적고 $P$ 값은 매우 크면, 상부 층은 투수성이 매우 높은 층류흐름이 발달하고, 하부로 내 려 갈수록 난류흐름이 크게 발달하게 된다. 따라서 $C$ 와 $P$ 값 의 관계를 통하여 난류흐름 구간과 수리단열의 특성을 파악 할 수 있다.(Fig. 9)

\section{라. 단열에 의한 우물수두손실}

다공질매질층에서의 우물수두손실은 케이싱 및 스크린, 시추시 공벽 변형 등의 다양하고 복합적인 원인에 의해서 발생하게 되지만, 단열암반대수층에서의 우물수두손실은 다공질매질층에 설치된 스크린과 같은 나공(open hole) 상 태의 단열특성에 의한 영향이 대부분일 것으로 판단된다. 관정을 향하는 단열들은 좁은 단열의 통로를 따라 지하수 흐름이 발생하거나 단열특성에 따라 지하수 흐름이 고투수 성 또는 저투수성 흐름을 가진다. 또한 단열에 대한 연결성 이 없거나 단열에 퇴적된 광물(depositional minerals) 및 거칠한 면의 접촉부(contact on asperity)로 인한 불투수성 구간에서는 수위강하가 발생한다. 단열특성에 따라 지하수 유속변화는 층류 및 난류흐름이 발생하게 되는데, 층류와 난류 흐름에 의한 지배적인 유동 변동의 특징에 의해서 나 타난다. 이와 같이 다공질매질에서의 우물수두손실 $\left(C Q^{p}\right)$ 은 케이싱 및 스크린 등에 의한 것이나, 단열암반대수층에 서 관통된 관정의 특성은 나공 상태에서의 단열들이 스크린 과 같은 우물수두손실로 해석되어 자연적 단열(natural fracture)에 의한 수두손실을 해석하는데 매우 유용하다.

각 단계별 양수율에 따른 단열암반대수층 구간에서의 수위 강하는 비수위강하량 $\left(s_{w}=Q\right)$ 으로 산정한 결과 값으로 고 · 저 투수성 단열에 대한 분석이 가능하다. 또한 단열암반대수층에 서의 우물수두손실항은 $C, Q$ 그리고 $P$ 값의 크고 작음에 따라 수리단열의 구간을 정량적 해석이 가능 할 것으로 판단된다.

\section{V. 토 의}

단계양수시험 해석을 이용하여 우물상수 $B, C$ 및 $P$ 를 결 정할 수 있고, 이 때 $B, C$ 및 $P$ 값을 알게 되면 시험해석으 로부터 영향을 받지 않는 연장된 수위강하를 보다 이상적으

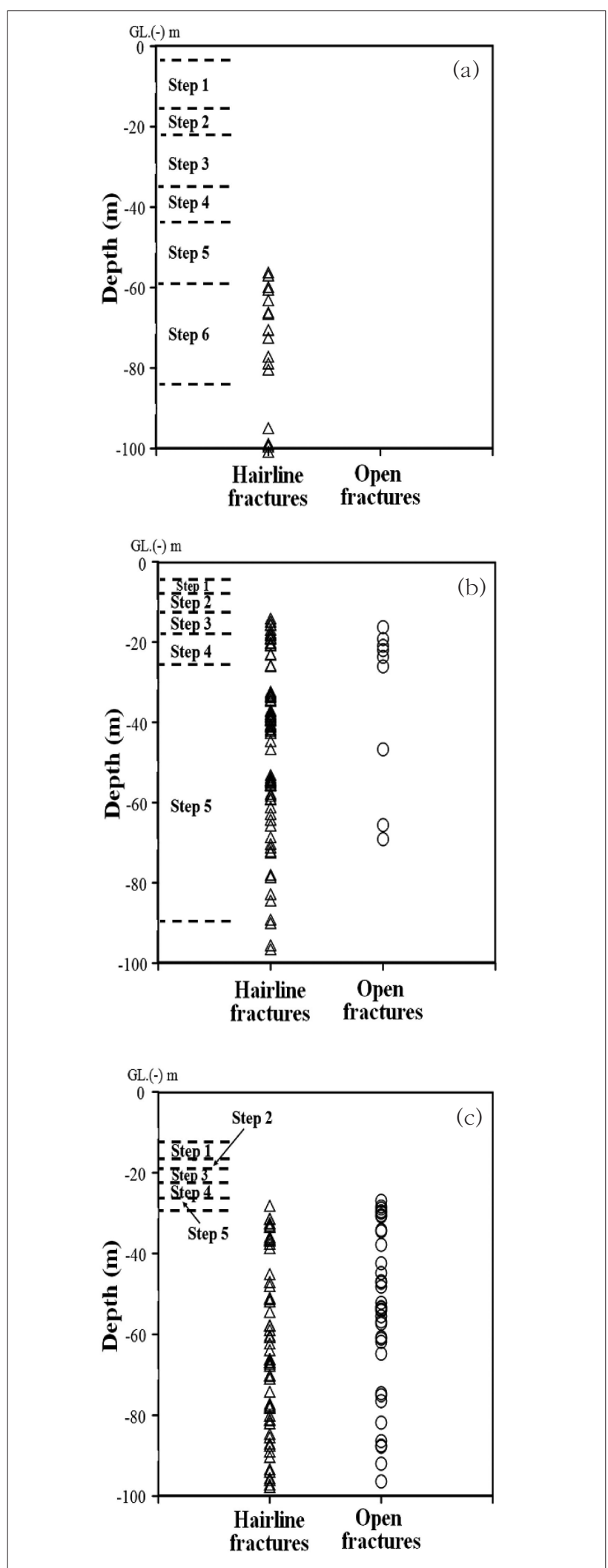

Fig. 9. Distributions of open and hairline fractures with depth variation; (a) CR-1, (b) CR-2, and (c) SR-1. 
로 예측할 수 있다. 또한 단열암반대수층의 경우 최소제곱 법으로 산정된 $C$ 와 $P$ 값의 범위에서 난류흐름과 수리단열 의 특성을 해석할 수 있는 장점을 가진다. 이러한 최소제곱 법은 비선형 함수를 기본으로 하는 단열암반대수층 뿐만 아 니라 다공질매질에도 매우 적합한 것으로 분석되었다[19].

단열암반대수층에서 시추된 양수정의 수위강하는 대수층 의 고유의 기질(geometry) 뿐만 아니라 양수정에서 양수 시 에 대수층의 비선형 변형에 영향을 받게 된다. 이러한 비선 형 모델을 이용한 대수층의 수리특성은 우물수두손실 항의 $C$ 와 $P$ 값의 관계로 해석할 수 있으며, 양수율 증가에 따른 $B, C$ 및 $P$ 값의 산정은 층류와 난류 흐름 구간을 파악할 수 있다. 단열암반대수층에서의 $P$ 값은 매우 중요하며 민감하 다. 일반적으로 Jacob은 양수율에 따른 수위강하의 기울기 는 다공질매질층이나 투수성이 높은 단열암반대수층에서는 선형적으로 증가하기 때문에 $P$ 값을 2 로 고정하였다. 그러나 Rorabaugh는 저양수량(low pumping)에서 $P$ 값은 2.43 2.82의 범위를, Labade and Helweg는 1 4의 범위를, Jha et al.는 수치해석의 전통적 방법(Levengerg-Marquardt 방법 과 Gauss-Newton Technique 방법) 및 비전통적 방법 (Genetic Algorithms)으로 산정한 $P$ 값의 범위는 1.60 6.03 의 범위를 갖는다고 하였다[2][26]. 상기 연구사례와 비교하 였을 때 본 연구로부터 산정된 $P$ 값의 범위는 3.459 8.290 의 범위로 높게 나타났다. 이와 같이 투수성이 매우 낮은 단 열 구간에서는 급격한 비선형적 기울기를 보이며, 이때 우물 수두손실과 관련된 $P$ 값과 난류흐름 구간은 확장되어 나타 난다. 그러나 동일 관정에서 투수성 단열 구간까지 수위강하 를 시키게 되면, 양수율에 따른 수위강하는 선형적으로 증가 하기 때문에 $P$ 값은 2값에 가깝게 나타난다. 저투수성 단열 구간에서 양수율 증가에 따른 수위강하 구간 범위를 어떻게 선택하는 것에 따라 우물수두손실과 난류흐름 구간이 다르 게 나타난다. 따라서 단열암반대수층에서 $P$ 값과 난류흐름 구간은 수리단열 특성에 따라 그 범위가 다르게 나타나기 때 문에 대수층 저심도까지 수위강하 구간을 대상으로 수리단 열 특성을 해석하는 것이 보다 정확할 것으로 판단된다.

국내에서는 단열암반대수층으로부터 양수시험과 물리검 층에 관한 비교 연구가 매우 부족한 실정이다. 그리고 단계 양수시험으로부터 우물상수 산정에 있어서 $C$ 와 $P$ 값이 독 립적인 변수인 점을 고려할 때 수위강하 구간범위에서 우물 상수가 우물효율 및 단열특성 해석에 어떠한 영향을 미칠 수 있는지에 관한 연구가 필요하다. 또한 단열암반대수층으로 부터 지하수유동차원 해석은 Bouredt et al.(1983)과 Spane and Wurstner(1993)가 제안한 수위강하 도함수(derivative)
의 기울기를 이용하여 분할유동차원 (fractional flow dimension)을 해석할 수 있으므로[27][28], 비선형적으로 증 가하는 $P$ 값의 해석은 다차원(multi-dimensions)적 수리단 열 특성을 이해하는데 한층 더 유용할 것으로 판단된다.

\section{VI. 결 론}

단열암반층에 굴착된 3 개의 양수정에서 단계양수시험이 실시되었다. 단계양수시험으로부터 획득된 자료는 선형모델 과 비선형모델의 최소제곱법을 이용하여 단열암반대수층의 우물상수들을 산정하여 비교 - 분석하였다. 그리고 우물수두 손실 항의 $C$ 와 $P$ 값에 대한 회귀분석 결과로부터 암반대수 층의 난류 구간과 수리특성의 관계가 파악되었으며, $C$ 와 $P$ 값의 관계로부터 단열암반대수층의 수리특성 해석에 있어 다 음과 같은 결과를 도출하였다.

단열암반대수층에서 적용된 선형모델의 경우 대수층수두손 실은 과소평가 되며, 우물수두손실은 과대평가 된다. 또한 매 우 급격한 수위강하의 영향으로 대수층수두손실이 (-)값을 보 이므로 적용할 수 없다. 따라서 단열암반대수층에서 비선형 모델은 관측 및 추정된 수위강하 사이의 제곱근 평균제곱오차 (RMSE) 값은 매우 낮으며, 추정된 수위강하 값은 관측된 수위 강하값과 매우 근접함을 확인할 수 있다. 이에 대한 $C$ 값은 $3.689 \times 10^{-19} \sim 5.825 \times 10^{-7}, P$ 값은 $3.459 \sim 8.290$ 의 범위로 산 정되어 수리단열의 빈도 및 연결성에 따라 단열특성이 매우 다양한 것으로 나타났다.

우물수두손실계수 $\left(C Q^{p}\right)$ 의 $C$ 와 $P$ 값의 회귀분석식 $P=1.7940-0.1565 \cdot \ln C$ 에서 $C$ 값의 감소에 따라 $P$ 값이 증 가하는 반비례 관계를 보였으며, 단열암반대수층에서의 우물 수두손실은 단열특성에 따라 난류흐름 구간을 해석할 수 있 다. 또한 단열암반대수층에서 우물수두손실 $\left(C Q^{p}\right)$ 의 $C$ 와 $P$ 값의 관계에 따라 층류흐름 구간의 투수성과 난류흐름 구 간이 상대적으로 확장되는 구간을 분석할 수 있다. 그리고 우 물수두손실과 관련된 $C$ 와 $P$ 값의 산정은 단열암반대수층에 서 난류흐름 구간과 수리단열의 특성을 해석하는데 매우 유 용할 것으로 판단된다.

\section{감사의 글}

본 연구는 2010년도 지식경제부의 재원으로 한국에너지 기술평가원(KETEP)의 지원을 받아 수행한 연구 과제입니다 (No. 201017102002D). 또한 일부 교육과학기술부의 원자력 연구개발사업의 일환으로 수행되었습니다. 


\section{References}

[1] C. E. Jacob, Drawdown test to determine effective radius of artesian well, Transactions, ASCE, 112, pp. 1047 1070 (1947).

[2] M. I. Rorabaugh, Graphical and theoretical analysis of step-drawdown tests of artesian wells, Proc. Am. Soc. Civ. Eng., 79, 362p (1953).

[3] D. H. Lennox, Analysis and application of stepdrawdown tests, J. Hydraul. div., Am. Soc. Civ. Eng., 92(HY6), pp. 25 47 (1966).

[4] N. T. Sheahan, Type-curve solution of stepdrawdown test, Ground Water, 9(1), pp. 25 29 (1971).

[5] Y. K. Birsoy and W. K. Summers, Determination of aquifer parameters from step tests and intermittent pumping data, Ground Water, 18(2), pp. 137 146 (1980).

[6] G. P. Kruseman and de N. A. Ridder, Analysis and evaluation of pumping test data, International institute for Land Reclamation and Improvement, Wageningen, the Netherlands, 2nd de. (completely revised), 377p (1991).

[7] W. H. Bierschenk, Determining well efficiency by multiple step-drawdown tests, International Association of Scientific Hydrology, 64, pp. 494 507 (1963)

[8] M. C. Kasenow, Production Well Analysis: New Methods and a computer program in well hydraulics. Water Resources Publications, LLC, Highlands Ranch, Colorado, 355p (1996).

[9] J. W. Labadie, and O. J. Helweg, Step-drawdown test analysis by computer, Ground Water, 13(5), pp. 438 444 (1975).

[10] N. T. Sheahan, Discussion of step-drawdown test analysis by computer, Ground Water, 13(5), pp. 445 〜49 (1975).

[11] A. D. Gupta, On analysis of step-drawdown data, Ground Water, 27(6), pp. 874 881 (1989).

[12] S. K. Singh, Optimization of confined aquifer parameters from variable rate pump test, J. Hydraul. Eng., 4(1), pp. 61 70 (1998).
[13] S. Shekhar, An approach to interpretation of step drawdown tests, Hydrogeology Journal, 14, pp. 1018 1027 (2006).

[14] C. T. Miller and W. J. Weber, Rapid solution of the nonlinear step-drawdown equation, Ground Water. 21(5), pp. 584 588(1983).

[15] G. J. V. Tonder, J. F. Botha, and J. V. Bosch, A generalised solution for step-drawdown tests including flow dimension and elasticity, Water SA, 27(3), pp. 345 354

[16] J. Y. Lee, S. H. Song, and K. K. Lee, Effects of Selected Time on Analysis Results in StepDrawdown Tests, Journal of Korean Society of Soil and Groundwater Environment, 10(2), pp. 59-65 (2005).

[17] J. Y. Lee, Problems in determining optimal discharge using step-drawdown tests, Journal of the Geological Society of Korea, 46(5), pp. 485 495 (2010).

[18] C. W. Lee, D. H. Lee, J. G. Jeong, K. Y. Kim, and Y. J. Kim, Well Loss in Fractured Rock Formation with Radial Flow during Pumping Test, Journal of Korean Society of Soil and Groundwater Environment, 7(4), pp. 17-23 (2002).

[19] S. Y. Chung, B. W. Kim, G.-B. Kim, and H. W. Kweon, Effects of Well Parameters Analysis Techniques on Evaluation of Well Efficiency in Step-Drawdown Test, The Journal of Engineering Geology, 19(1) pp. 71-79 (2009).

[20] K. W. Park, S. H. Ji, Y. K. Kho, G. Y. Kim, and J. K. KIM, Numerical simulation of groundwater flow in LILW Repository site: II. Input parameters for Safety Assessment, Journal of the Korean Radioactive Waste Society, 6(4), pp. 283-296 (2008).

[21] M. Oden, A. Niemi, C.-F. Tsang, and J. Ohman, Regional channelized transport in fractured media with matrix diffusion and linear sorption, Water Resouces Research, 44, W02421,doi:10.1029/ 2006WR005632 (2008).

[22] Ministry of Construction and Transportation, Korea Water Resources Corporation, and Korea Resources 
Corporation, Groundwater survey of CheongwonChengju Area, Government Publications Registration Number (1-1500000-001810-01), 7-7 (2006)

[23] Daewoo E\&C, Post-construction safety assessment report of underground library at the Busan Branch, the National Archives of Korea near a access tunnel on Gyeongbu KTX train line (Reach 14-2), $752 \mathrm{p}$ (2004).

[24] V. Batu, Aquifer Hydraulics- A comprehensive guide to hydrogeologic data analysis, John Weley \& sons, New York, pp. 113 627 (1998).

[25] D. K. Todd, Groundwater Hydrology, John Wiley \& Sons, New York, pp. 111 163 (1980).

[26] M. K. Jha, A. Kumar, G. Nanda, and G. Bhatt, Evaluation of Traditional and Nontraditional Optimization Techniques for Determining Well Parameters from Step-Drawdown Test Data, Jouranl of Hydrologic Engineering, 11(6), pp. 617 630 (2006).

[27] D. Bourdet, T. M. Whittle, A. A. Douglas, and Y. M. Prirard, A new set of type curves simplifies well test anal;ysisi, World Oil, May 1983, pp. 95 106 (1983).

[28] F. A. Jr. Spane, and S. K. Wurstner, DERIV: A computer program for calculating pressure derivative for use hydraulic test analysis, Groun Water 31(5), pp. 814 822 (1993). 